\title{
Inflation and Its Cure
}

\author{
by NORMAN N. BOWSHER
}

$\mathbf{P}$ RICES HAVE INCREASED ever more rapidly since 1965, and in the past year overall prices have risen more than 5 per cent. The inflation has redistributed income and wealth and contributed to inefficiency. The Government began taking actions in mid-1968 designed to restrain inflation. Since eliminating inflation, by necessity, involves costs, a course: of gradual correction has been followed with the objective of holding such costs to a tolerable level.

In this article, recent developments are reviewed with the objective of throwing some light on: 1) progress made in reducing inflation; 2) costs of adjusting to the inflation; and 3) costs generated by the struggle to reduce the inflation.

As in two previous articles in this Review, the current situation is compared with three earlier periods of economic correction. August 1969 is used here as a tentative beginning for the current adjustment, since it is the middle of the quarter when output of goods and services was greatest. Developments since August are compared with developments in the corresponding periods after the July 1953, July 1957, and May 1960 peaks, as selected by the National Bureau of Economic Research. These three earlier periods were quite mild corrections judged in the light of longer experience in modern economic history.

\section{Progress Against Inflation}

Inflation has proceeded at a faster and faster rate since 1964. Overall prices, which had been rising less

$1^{i z}$ Downturn Remains Mild" this Review (June 1970), pp. 2-7, and "Extent of the Slowdown," this Review (March 1970), pp. $2-5$ and $14-16$. than $1^{1 / 2}$ per cent a year in the early $1960^{\mathrm{s}} \mathrm{s}$, increased 2 per cent in $1965,3.5$ per cent in 1966 and 1967 , 4 per cent in 1968, and 5 per cent in 1969. The acceleration of price advance reflected a rise in total spending for goods and services at an average 8 per cent annual rate from late 1964 to late 1969 , or roughly double the rise in production capacity. The excessive rise in total spending was fostered by generally expansive fiscal and monetary actions from 1964 through 1968."

From the third quarter last year to the second quarter this year, overall prices rose at an estimated 5.3 per cent annual rate, even faster than the 5 per cent increase in the previous year. To many, this is evidence that the struggle against inflation has failed. However, prices respond to many factors, including lagged effects of previous excesses, and since the current period of correction follows about four years of growing inflationary pressures, some temporary continued acceleration of price rises was to be expected.

As inflation intensifies, it becomes more resistant to corrective measures, and prices continue to rise for a period after excessive "demand-pull" pressures on resources and prices are removed. In the year before the three previous business cycle peaks, prices rose an average of 2 per cent. In the first two quarters of the correction periods, prices rose at an average 2.3 per cent annual rate. Thereafter, the rate of price rise began moderating. The strong upward thrust of prices during the initial phase of restrained spending growth may reflect the fact that spending, although dampened, may nevertheless be excessive for a few $2^{* 1968-Y e a r}$ of Inflation," this Review (December 1968),
pp. 3 14. 
months. Further, many prices and wages do not adjust immediately in the presence of unduly large demand pressures. This may be due to inertia, lack of knowl. edge of real costs, public opinion, regulations, contracts, or a money illusion. These lagging price adjustments place "cost-push" forces on other prices when they do occur. Consequently, success in the struggle against infation, once it has been permitted to gain momentum, takes time.

A quick dampening of inflation is even less likely now than in the 1953-54, 1957-58 or 1960-61 periods for several reasons: the upward thrust of prices has been much stronger than during the earlier periods; policies to resist inflation have been milder; and their impact on spending has been less. Total spending on goods and services has slowed only moderately since the third quarter of last year to an estimated 4 per cent annual rate of increase. In sharp contrast, spending declined at a 2 per cent average rate in the corresponding periods of the three previous adjustments.

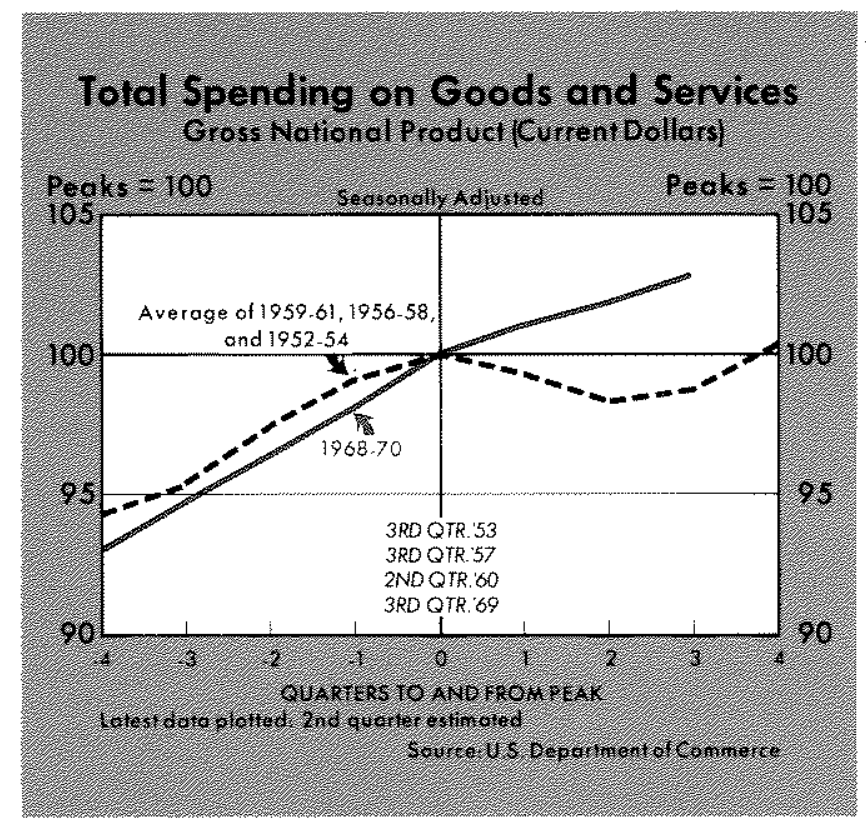

Other developments also reflect the gradualism of the recent approach to resisting inflation. Retail sales rose at an estimated 4 per cent annual rate from August to May, a slightly greater rate than in the previous year. In the corresponding nine months after the three previous peaks, retail sales declined at a 2 per cent average rate. Personal income, likewise, has slowed little since last August in marked contrast to earlier experiences.

With growth of total spending held to rates approximating growth in the nation's productive capacity, progress is probably being made at reducing inflation- ary pressures. Comparisons with previous experiences, when inflation was less ingrained and when antiinflationary measures were pursued more aggressively, indicate that a substantial reduction of the current inflation will take a long time. According to estimates of this bank, if the gradual approach to resisting inflation is continued, substantial price stability may not be achieved for three more years. ${ }^{3}$

\section{Costs of Adjusting to Inflation}

The costs of inflation have been substantial and far-reaching. Some have suggested that once inflation becomes fully anticipated and provided for in all contracts and other transactions, its cost would be very light, perhaps even zero. However, the current inflation has not been fully anticipated, and while some adjustments to it have been made, many others have not. As a result, the inflation has had, and is likely to continue to have, severe consequences. In brief, inflation reduces the value of money and other dollar-denominated assets relative to the value of other assets, causing a redistribution of wealth and income. The process of adapting to higher and higher rates of inflation, given existing contracts, laws, and other rigidities, causes inefficiencies, inequities, and interruptions to production.

Some costs that society has suffered in the process of adjusting to higher and higher rates of inflation have been incorrectly labeled a cost of resisting inflation. One example is the capital loss experienced by some bondholders in recent years. Some have said interest rates have been increased (bond prices lowered) in an attempt to reduce the excessive spending by making credit more costly and difficult to obtain. It has been suggested that this raising of interest rates has proceeded so rapidly that it has fostered fears of a liquidity squeeze or money panic.

However, most of the rise in interest rates (decline in bond prices) since the mid-1960's has probably been a result of a market adjustment to higher and higher price expectations. With inflationary anticipam tions, lenders seek to protect the purchasing power of funds by raising rates, while borrowers pay higher rates, expecting to repay in depreciated dollars. If both borrower and lender expect 5 per cent inflation during the period of the loan, and funds are worth a real 4 per cent, the interest rate stated in the contract will be 9 per cent, and existing 4 per cent bonds will

\footnotetext{
3 For a discussion of the procedure used to derive these estimates, see "A Monetarist Model for Economic Stabiliza tion," this Review (April 1970), pp. 7-25, and the "Quarterly
} Economic Trends" release of this Bank. 


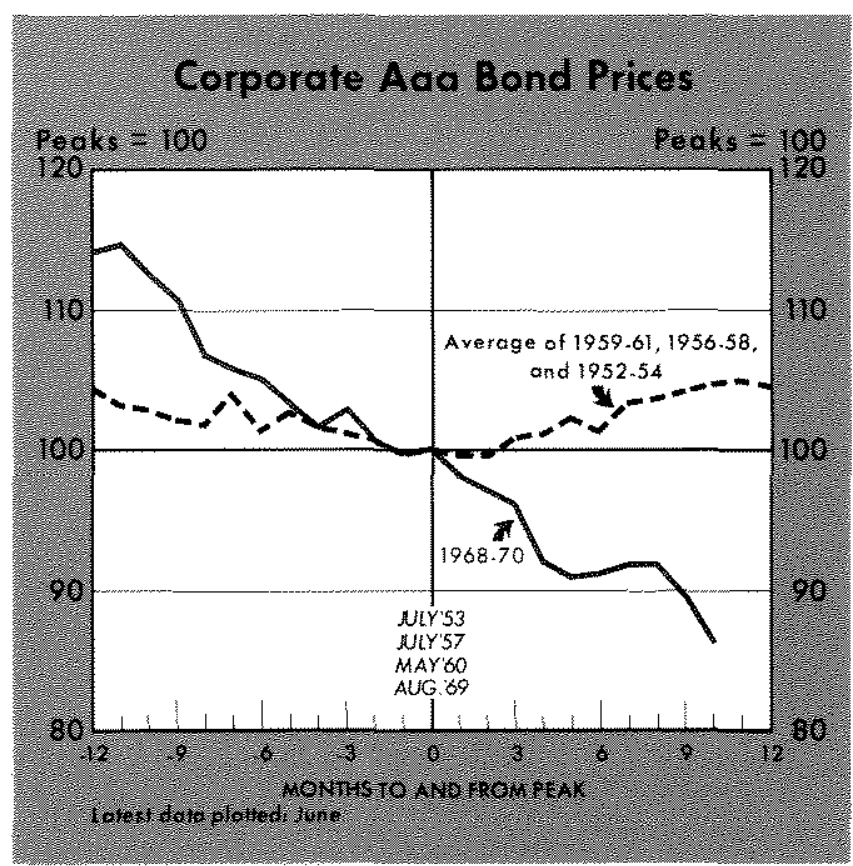

fall in market price sufficiently to yield 9 per cent a year to maturity. ${ }^{4}$

Prices of highest-grade seasoned corporate bonds declined (yields rose) 14 per cent from last August to June. In the corresponding ten-month periods of the three earlier adjustments, these bond prices rose 5 per cent on average. Monetary restraint was actually greater in the three earlier periods, as measured by a slower injection of bank reserves and money. A major difference between the recent situation and the earlier periods is that price expectations have apparently continued to be revised upward, while at similar stages of earlier cycles, when smaller inflations were more aggressively resisted, price expectations had already begun to be revised downward.

Stock prices have nearly paralleled the pattern of bond prices, and possibly for the same reason. As investors revise their inflationary expectations upward, the retum anticipated from dividends and stock appreciation increases. When inflationary expectations go up from, say, 2 per cent a year to 5 per cent, and yields on bonds go up from, say, 6 per cent a year to 9 per cent, long-run expected stock returns (dividends plus appreciation) may go up from, say, 9 per cent a year to 12 per cent. Because of contracts, regulations, inertia, and other rigidities which restrain cor-

$4^{4}$ Interest Rates and Price Level Changes, 1952-69," this Review (December 1969), pp. 18-38. This example ignores the income tax consideration for both lender and borrower; actually with the assumptions of 4 per cent real return and 5 per cent anticipated inflation, the market rate would be higher than 9 per cent.

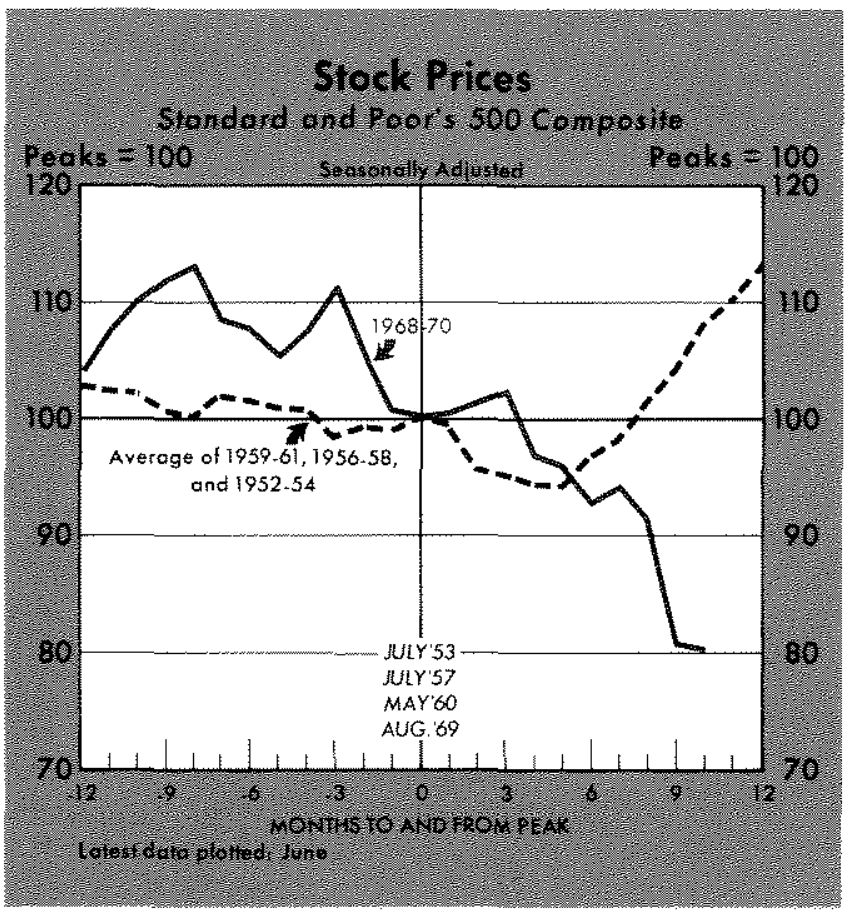

porations from maximizing returns on capital in the short run, part of this adjustment for existing stocks may be accomplished in the market by a lowering of prices. In the long run, however, stock prices will reflect the inflated cost of resources going into capital formation.

From last August to June, stock prices (Standard and Poor's 500 Composite) fell 20 per cent. After ten months of the three previous recessions, stock prices had already risen an average 9 per cent above their levels at the business cycle peaks. The sharply different experience apparently cannot be fully explained by a weaker business situation this time. Corporate profits after taxes declined at a 14 per cent annual rate from the third quarter last year to the first quarter this year. In the corresponding two quarters in the previous corrections, corporate profits fell at a 28 per cent average rate.

Stocks and bonds are not the only assets that are affected in value by rising inflation and inflationary expectations, but more attention is given to these markets because of widespread availability of frequent quotations. The value of mortgages and other debts have declined similarly. The purchasing power of most pensions has been reduced. Also, lessors (unless protected by escalators) have suffered a decline in real estate values. On the other hand, inflation has given windfall gains to debtors and holders of some other types of assets, contributing to inequities among individuals. 


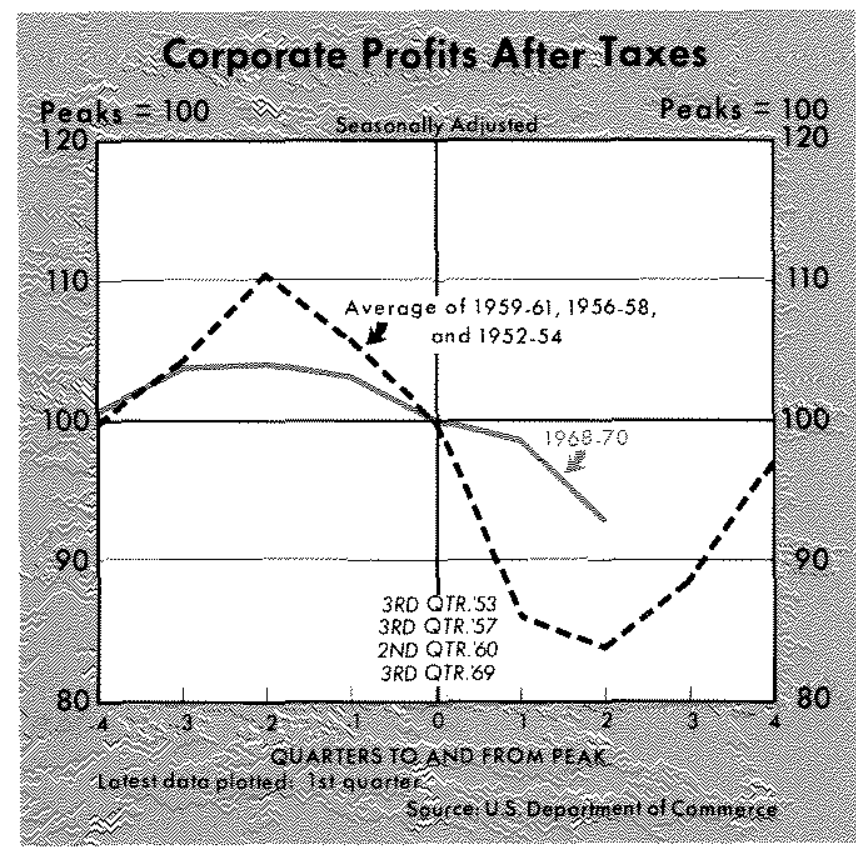

Costs in Reduching Inflation

Once inflationary expectations become strong, it is difficult and costly to extinguish them. Commitments made on the expectation of continued inflation become more difficult to fulfill if the inflation is less than anticipated. When excessive spending is dampened, many prices do not move quickly to their equilibrium levels, and declines in production and employment result. As noted above, growth of total spending has slowed since last August to about the trend rate of growth in capacity. Since overall prices have continued to rise rapidly, there have been cutbacks in output and production.

The recent slowdown in production is a cost necessary to limit price increases. If spending growth continues to be appropriately limited, prices gradually will rise more slowly, and production will improve as prices rise less rapidly.

It may be, however, that much of the adjustment in production to date has merely been a transitional cost to a fuller anticipation of the inflation. In the initial stages of accelerating inflation, economic activity receives a stimulus. Individuals and businesses with greater money balances than they desire to hold increase their spending even at higher prices, the greater spending causes businessmen to revise upward their profit expectations, and investment is expanded. However, since total spending is excessive, prices are bid up. Costs are higher and profits lower than expected in real terms. As a result, when the rate of inflation becomes more fully anticipated, its stimulative effects diminish, and growth rates of spending, production and employment slow to their trend rates, or even below for a brief adjustment period. In the following discussion an attempt is made to gain some insight into the magnitude of production cutbacks, without attempting to judge whether they are a result of an adjustment to a higher rate of inflation or are a result of a burden assumed to place downward pressure on prices.

Total real output, like total spending, has reacted much less since last summer than during the three previous periods of correction. From the third quarter last year to the second quarter this year, real production declined at an estimated 1.3 per cent annual rate. In the first three quarters of previous periods of adjustment, real output doclined at an average 3.4 per cent rate.

Industrial production, like total real product, has changed much less than in the three recessions. The decline in industrial production at a 4 per cent rate from last August to May was much less than during the first nine months of any of the previous periods of adjustment, when production fell at an average 14 per cent rate.

Employment trends have been stronger in late 1969 and early 1970 than following the upper turning points of the three earlier cycles. Since last August, payroll employment has increased slightly, while in the corresponding ten months of each of the three previous correction periods it had declined at an average annual rate of 3.5 per cent.

A high level of utilization of the potential labor force is conducive to continued strong upward pressure on wages. In June total civilian employment was equal to 64 per cent of the population of working

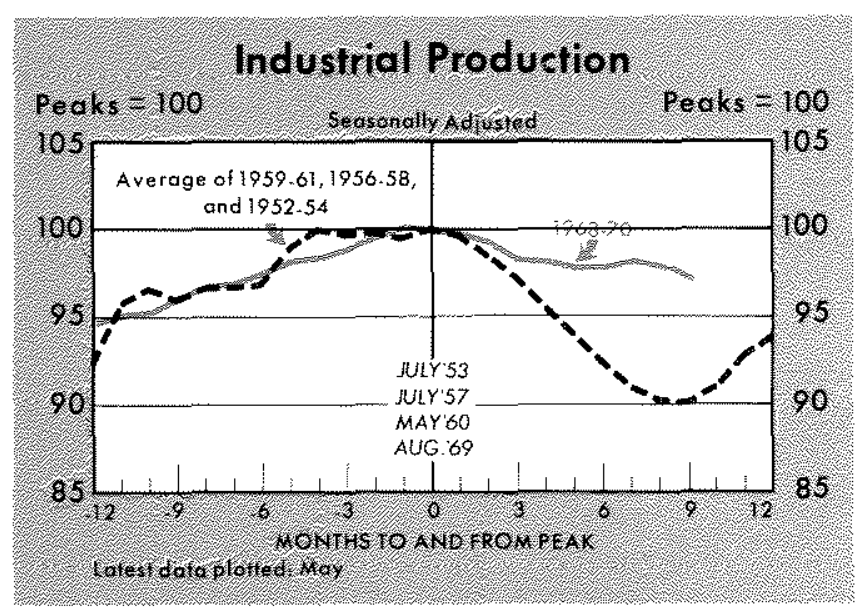




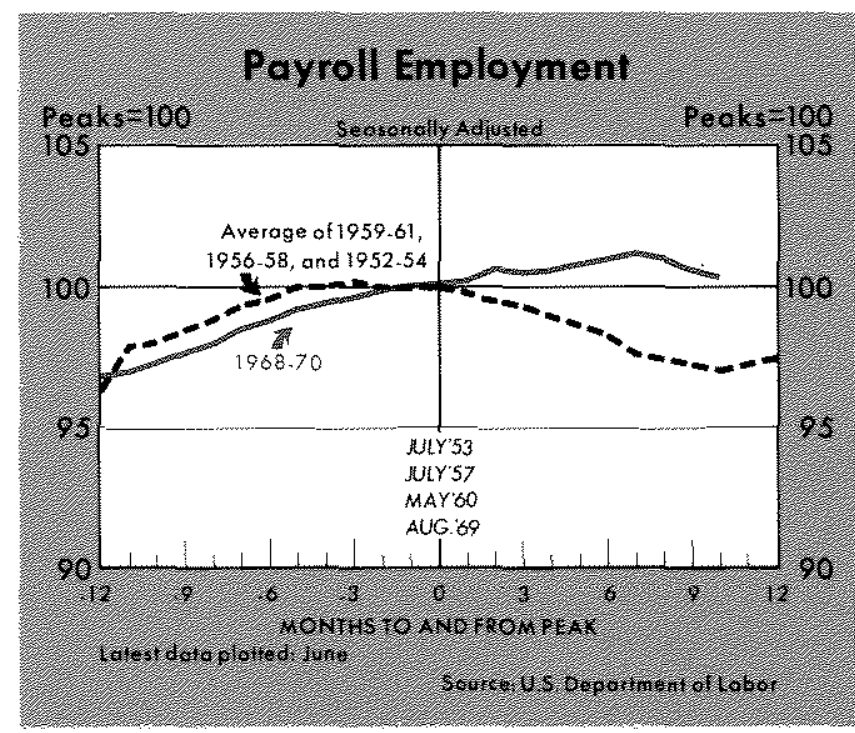

force age (16 through 64 ). In the sixteen years from 1950 through 1965 this ratio never exceeded 63.5 and declined to as low as 60 . A somewhat lower utilization of the labor force is likely in the near future even if total production rises somewhat, since productivity gains and growth of population of labor force age will provide for some increase in output.

Construction is one area where cutbacks have been as great or greater than in the three previots recessions. It may be that construction is being adversely affected much more from the increasing inflation than from the efforts to reduce inflation. Construction has been hurt more than most industries by rising labor, material, and land prices. Since large amounts of long-term borrowed funds are used in purchasing homes and other buildings, construction has also been affected seriously by the higher interest rates, resulting from the rising price anticipations. Construction has suffered further from heavy financial disintermediation (resulting from Regulation $Q$ ceilings and similar rules), and from state usury laws which have favored large businesses and others who can obtain funds in the free capital markets.

\section{Recent Srobilzation Actions}

In implementing the gradual anti-inflationary program of the Government, fiscal actions have been moderately but steadily restrictive in 1969 and 1970 . Since the first quarter of 1969, the high-employment budget surplus, as estimated by this bank, has been in the $\$ 7$ to $\$ 11$ billion range. This measure, unlike other measures of Federal Government fiscal developments, excludes most of the effect on the budget of changing levels of real economic activity, so as to observe more clearly the effect of Government actions on the economy. The surplus in this budget is expected to decline only slightly during the summer and fall.

The fiscal restraint since the end of 1968 has been achieved, in large measure, by a cutback in defense spending. National defense outlays have declined at a 0.4 per cent annual rate since the fourth quarter of 1968, after rising 13 per cent annually in the four previous years. In the first half of 1970 , defense spending amounted to less than 8 per cent of total gross national product, compared with an average of 9.4 per cent from 1957 through 1963. Nondefense

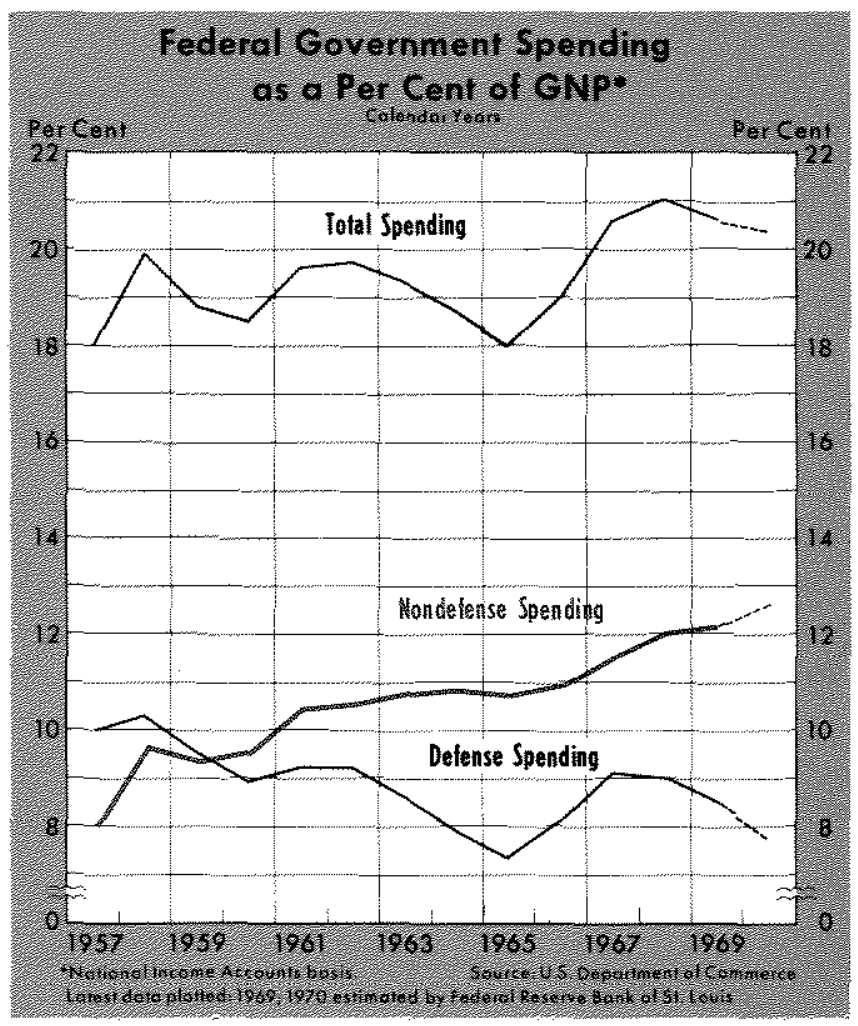

expenditures have risen at an 8 per cent rate since the fourth quarter of 1968 , following a 12 per cent rate in the previous four years. On the other hand, the Government, by removing the surtax in two steps, January 1 and July 1, 1970, took partially offsetting expansive actions.

The current fiscal restraint, as measured by the high-employment surplus, is much milder than during the 1959 -61 period of correction and, relative to the size of the economy, is even less than during the 1956-58 period. The $1953-54$ adjustment, which was the longest period of correction reviewed here, occurred paradoxically at a time when the budget was expansive. 
Indications are that Federal budget requirements will place large demands on money and capital markets in coming months. The Government's official. budget, in contrast with the high-employment budget, is shiding into deficit because of a marked slowing in $\operatorname{tax}$ collections. When this factor is added to the planned activities of Govemment agency and loan guarantee operations, the Federal Govemment's demand for funds (both direct and indirect) in fiscal 1971 appears likely to be the largest since fiscal 1968.

Monetary authorities also have followed a comparatively moderate course in resisting inflation. Monetary action, as measured by growth of the money stock, was restrictive from early 1969 to February 1970. In the first half of 1969 money rose at a 4 per cent annual rate, down from a 7 per cent rate in the two previous years. From June 1969 to February 1970 the money stock was virtually unchanged.

This recent monetary restraint was more moderate than during the other periods of correction, probably contributing to the mildness of the current adjustment. On average the money stock in the earlier periods remained on a plateau from ten months before the peak until six months after the peak.

Since February, money has risen at a very rapid 7 per cent annual rate. This is much faster than during the relaxation periods following past periods of economic correction, and it began sooner; that is, the sixth month after the peak, compared with an average of nine months after the previous peaks. The growth in money since February approximates the expansive growth in early 1967.

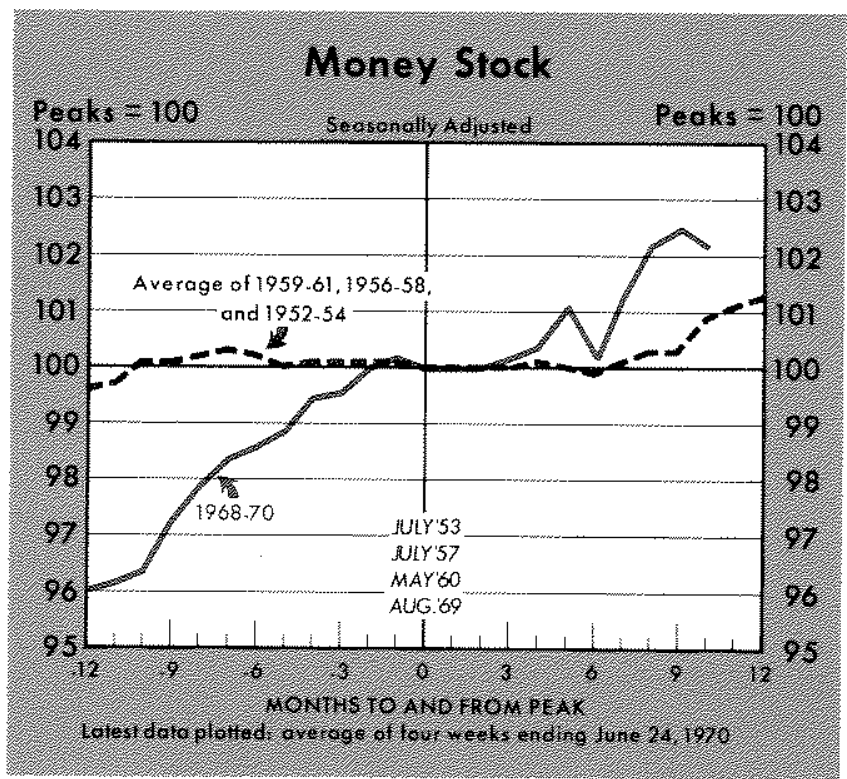

\section{Conclusions}

Inflation has been accelerating sinee the end of 1964. Actions taken to resist the inflation have been more carefully applied than during previous periods of economic correction. As a result, total spending has continued to rise at a near long-run optimum growth rate. Prices have continued to rise rapidly, and production has declined slightly.

Continued price increases are disheartening, especially when there is growing slack in productive capacity. However, in view of the strong upward momentum built into the price structure by the expansive fiscal and monetary actions from 1964 through 1968, and in view of the moderate character of the policy steps taken to resist the inflation, it is unlikely that a substantial improvement will materialize for a considerable period. A more aggressive attack on inflation might have produced quicker results, but at the expense of harsher transitional costs in terms of real product, employment and profits.

The current inflation and the struggle against it have been accompanied by costs. Production has declined, construction has been depressed, growth in employment has slowed, and stock and bond prices have fallen. Questions have been raised as to whether the cost of even the gradual approach in reducing inflation is too great. Yet, many of these supposed costs of fighting inflation are, in fact, the result of the economy adjusting to higher expected levels of inflation. If spending continues to rise moderately, as it has for a year, some of these costs of adjusting to greater expected inflation should soon subside. On the other hand, costs involved in actually reducing the strong inflationary anticipations, which have probably been moderate, may intensify and continue for some time.

There is some evidence that the battle against inflation may be postponed again as in 1967. Spokesman for those hurt seek renewed economic stimulation, without distinguishing whether the pain has come from adjustments to higher rates of expected inflation or from adjustments to lower rates. Pressures are building to expand Govemment outlays, monetary expansion has been rapid since February, and unrealistic hopes are being placed on attempts to talk prices down. Each time a final showdown with inflation is postponed, the total costs of adjusting, first to a still higher rate of expected inflation and ultimately to a lower rate, become greater. 